\title{
Dil ve Mantık İlişkisi Üzerine Bir Değerlendirme
}

\author{
Coşkun Baba \\ Dr., Bartın Üniversitesi, İslami İlimler Fakültesi, Mantık Anabilim Dalı \\ Dr., Bartın Universty, Faculty of Islamic Sciences, Department of Logic \\ Bartın, Turkey \\ cbaba@bartin.edu.tr \\ orcid.org/0000-0002-4056-085X
}

\section{An Assessment of the Relationship Between Language and Logic \\ Abstract}

Human being is a thinking and talking creature. Human being differentiates itself from other creatures by being a talking and thinking creature. Human being exports his emotion, thought, experience, knowledge and skill through language. People can use the language to communicate among themselves as long as they exist. It is important to use the language correctly, properly and consistently while communication takes place. Therefore, people should use language correctly and consistently while sharing their thoughts among themselves. In addition, logic is needed for shared thinking to be consistent.

Human being needs language and logic to make sound thinking, to make accurate and precise judgments and to use valid and consistent arguments. Language, which is the most important sign and means of human and civilization, allows people to express their feelings, thoughts and desires, as well as maintain their lives. Language, which is the carrier of thought or meaning, is indispensable for the transmission of thought. When the logic, which plays an important role in the thought being correct and consistent, is known, we can say that the truth can be distinguished from the wrong and invalid, as well as the comprehension of the meaning from the wrong one. The subject of logic is logical thinking. Therefore, logic is defined as "knowledge of correct thinking rules". The common denominator of logic and language is 'thinking'. Because both logic and language are closely related to 'thinking'. Considering the relationship of language with thought and the relationship of thought with logic, logic is also closely related to language.

Logic is the means of thinking right. Language is the dress of thought. It is essentially thought that shapes the language or shapes the language. Thoughts must be expressed in language, because if we do not express our thoughts in language, we will not be able to analyze them logically. Reasoning is a form of thinking. Reasoning needs to be expressed in language and take the form of an argument. Arguments also form the subject of logic. It can be said that logic is actually an outward process that continues with thought and has the opportunity to express itself through language. When logic is said, it is thought to express the language with thought. For this reason, language, thought and logic have a strict and tight relationship among themselves.

Thanks to logic, the act of thinking is healthy, sound (in terms of knowledge), consistent and accurate. The correct thought regulated by the rules of logic goes wrong when there are no logic rules. Hence, if sound thought has occurred thanks to logic, the possibility of a sound language has increased.

İtihal Taraması/Plagiarism Detection: Bu makale intihal taramasından geçirildi/This paper was checked for plagiarism Geliş/Received: 05 Ocak/January 2020 |Kabul/Accepted: 17 Şubat/February 2020 | Yayın/Published: 20 Mart/March 2020 Atıf/Cite as: Coşkun Baba, "Dil ve Mantıkiliş̧kisi Üzerine Bir Değerlendirme= An Assessment of the Relationship Between Language and Logic”, Eskiyeni 40 (Mart/March 2020), 95-106. https://doi.org/10.37697/eskiyeni.670492

Copyright @ Anadolu Illahiyat Akademisi/Anatolian Theological Academy, 06050, Ankara, Turkey |www.anilakademi.com CC BY-NC 4.0 | This paper is licensed under a Creative Commons Attribution-NonCommercial License 
One of the reasons why we can easily talk about the existence of a close relationship between language and logic is: Grammar gives the rules of speaking correctly and logic thinking correctly. What language relates to words is the relationship between logic and concepts. However, logic refers to the laws of the thought of all mankind, while it contains rules about the language of a grammatical nation. Logic, which protects our minds from falling into error, finds a space for expression through language. Thoughts and concepts that qualify as right or wrong occur through language. Therefore, in order to determine the logical validity of any reasoning, it must be expressed through language and gained an argument form. So logic deals with arguments that are the linguistic expression of reasoning. Therefore, the logic that deals with arguments has a bond and relationship that does not break with language.

Logic means internal speech and external speech. The inner speech is the mind-setting of the minded meanings. The logic renders the outer speech error-free after solidifying the inner speech phase. Foreign speech takes place in language. It is possible for language to change from very meaningful to single meaning with the rules of logic. In short, we can say that internal speech is logic and external speech is language designed with logic rules. For this reason, language and logic belong to a whole. A person who seeks to think logically, to make the right judgments and to use valid arguments first needs reason, logic and language. Therefore, logic and language play an important role in conducting a healthy communication. For this reason, logic and language are needed for communication. Consequently, language and logic must be together. In this case, it shows us that the relationship between language and logic must always continue strongly.

In short, people who use language in all areas of life must also use logic. Because if the human does not act in accordance with the rules of logic, it is inevitable for the human mind to fall into error. For this reason, logic is important together with language in the lives of people who are often in communication. Because logic without language and language without logic is insignificant. Therefore, it is not possible to think of "language" without "logic" and "logic" without "language".

\section{Keywords}

Logic, Language, Thought, Communication, Language-Logic Relationship

\section{Dil ve Mantık İlişkisi Üzerine Bir Değerlendirme}

\section{Öz}

İnsan düşünen ve konuşan bir canlıdır. İnsan, konuşan ve düşünen bir canlı olma özelliğiyle kendisini diğer canlılardan farklı kılmaktadır. İnsan, duygusunu, düşüncesini, tecrübesini, bilgisini ve becerisini dil sayesinde dışa aktarmaktadır. Dil, iletişim araçlarından birisi olması nedeniyle insanlar var olduğu süre içerisinde kendi aralarında iletişim kurmak için dili kullanabilir. İletişim gerçekleşirken dil kadar dilin doğru, düzgün ve tutarlı bir şekilde kullanılması da önemlidir. Bundan dolayı insanlar kendi aralarında düşüncelerini paylaşırken dili doğru ve tutarlı kullanmalıdırlar. Bunun yanında paylaşılan ya da aktarılan düşüncenin tutarlı olabilmesi için mantığa ihtiyaç vardır.

Sağlam düşünme, doğru ve kesin yargılarda bulunma ile geçerli ve tutarlı argümanlar kullanma amacında olan insanın düzgün iletişim kurmasının yanında sağlam düşüncelerini aktarması için dile ve mantığa ihtiyacı vardır. İnsanın ve uygarlı̆̆ın en önemli belirtisi ve vasıtası olan dil, insanın duygularını, düşüncelerini, arzularını dışa vurmasına imkân sağladığı gibi hayatını sürdürmesine de olanak sağlar. Düşüncenin aktarılması bağlamında düşüncenin veya anlamın taşıyıcısı olan dil, düşüncenin aktarımı için olmazsa olmazıdır. Düşüncenin doğru ve tutarlı olması hususunda önemli rol oynayan mantık bilindiğinde, sözün doğrusunu yanlış ve geçersizinden ayırt edilebildiği gibi manayı doğru kavramayı da yanlış olanından ayırt edilebilir diyebiliriz. Mantığın konusu mantıksal düşünmedir. Bundan dolayı mantık, "doğru düşünme kurallarının bilgisi” diye tanımlanmaktadır. Mantık ve dilin ortak paydası 'düşünme'dir. Çünkü hem mantık hem de dil, ‘düşünme' ile sıkı ilişki içerisindedir. Dilin düşünceyle olan ilişkisi ve düşüncenin de mantıkla olan ilişkisi dikkate alındığında mantık dil ile de sıkı ilişki içerisindedir. 
Mantık, doğru düşünmenin vasıtasıdır. Dil de düşüncenin elbisesidir. Dili şekillendiren ya da dile şekil veren esasında düşüncedir. Düşüncelerin mutlaka dil ile ifade edilmesi gerekir, zira düşüncelerimizi dil ifade etmezsek mantıksal açıdan incelebilmemiz söz konusu olmayacaktır. Akıl yürütmeler bir tür düşünme biçimidir. Akıl yürütmelerin dil ile ifade edilmesi ve argüman şeklini alması gerekir. Argümanlar da mantığın konusunu oluşturur. Mantık, aslında düşünceyle beraber varlığını sürdüren ve dil sayesinde kendini dışa vuran bir süreç olduğu söylenebilir. Mantık denildiğinde düşünceyle birlikte hangi şekilde ya da koşulda olursa olsun dilin, diğer bir ifadeyle düşünülenin ifade edilme hali akla gelmektedir. Bundan ötürü dil, düşünce ve mantık kendi aralarında kesin ve sıkı bir ilişkisi içerisindedir.

Mantık sayesinde düşünme eylemi sağlıkl, sağlam (bilgi açısından), tutarlı ve doğru olmaktadır. Mantık kuralları ile düzenlenen sağlıklı, sağlam, tutarlı ve doğru düşünce, mantık kuralları olmadı̆̆ında yanlş̧a düşmektedir. Buradan hareketle; mantık sayesinde sağlam düşünce oluşmuş ise sağlam düşünceden sağlam bir dilin ortaya çıkma ihtimali de artmıştır.

Dil ile mantık arasında sıkı bir ilişkinin varlı̆ından rahatlıkla söz ediyor olabilmemize etken sebeplerden birisi de şudur: Dilbilgisi hatasız konuşmanın, mantık da doğru düşünmenin kurallarını vermektedir. Dilin lafızlarla olan ilişkisi ne ise mantığın kavramlarla ilişkisi de öyledir. Şu var ki gramer bir milletin dili ile ilgili kuralları içerirken mantık bütün insanlığın düşüncesine ait kanunları ifade etmektedir. Zihnimizi hataya düşmekten koruyan mantık, dil sayesinde kendisine ifade alanı bulur. Doğru ya da yanlış şeklinde nitelendirilen düşünceler ve kavramlar dil vasıtasıyla meydana çıkar. Dolayısıyla herhangi bir akıl yürütmenin mantıksal açıdan geçerliliğini belirleyebilmek için o akıl yürütmesinin dil vasıtasıyla dışa vurulup bir argüman biçimi kazanması gerekmektedir. Bundan dolayı mantık, akıl yürütmelerin dilsel ifadesi olan argümanlarla ilgilenir. Bu nedenle de akıl yürütmelerin dilsel ifadesi olan argümanlarla ilgilenen mantık dil ile kopmayan bir bağı ve ilişkisi vardır.

Mantık, iç konuşma ve dış konuşma manalarına gelmektedir. İç konuşma, akledilmiş olan manaların anlaşılması, bir başka ifadeyle akledilmiş anlamların zihni düzenlemesidir. İç konuşma aşamasını sağlam bir hale getiren mantık daha sonra dış konuşmayı yine kendi kuralları ile hatasız, sağlam ve mükemmel hale getirmektedir. Dış konuşmanın gerçekleşmesi dil ile olmaktadır. Dilin çok anlamlııktan kurtulup tek anlamlı hale gelmesi mantığın kuralları ile mümkündür. Kısaca iç konuşmanın mantık, dış konuşmanın ise mantık kuralları ile dizayn edilmiş dil olduğunu söyleyebiliriz. Bu sebepledir ki dil ve mantık bir bütüne aittir.

Mantıklı düşünme, doğru yargılarda bulunma ve geçerli argümanlar kullanma amacında olan insanın bu amacını yerine getirebilmek için öncelikle akıl, mantık ve dile ihtiyacı vardır. Dolayısıyla burada olduğu gibi iletişim sırasında da iletişimin sağlıkl yürütülebilmesi için mantık ile dil önemli rol üstlenmektedirler. Bu sebeple iletişim için mantık ve dile ihtiyaç vardır. Netice itibariyle dil ile mantık birlikte olmak durumundadırlar. Bu durumda bize göstermektedir ki, dil ile mantık arasındaki ilişki her zaman güçlü bir şekilde devam etmek zorundadır.

Kısaca hayatın her alanında dili kullanan bir varlık olarak insan mantığı da kullanmak durumundadır. Zira insan, mantı̆̆ın kurallarına uygun hareket etmezse insan zihninin hataya düşmesi kaçınılmazdır. Bu sebeple mantık, çoğu zaman iletişim halinde olan insanların hayatında dil ile birlikte önem arz etmektedir. Çünkü dil olmadan mantık, mantık olmadan da dil önemsizdir. Bundan dolayı da 'mantık'sız 'dil', 'dil'siz 'mantık' düşünmek tasavvur edilemez.

\section{Anahtar Kelimeler}

Mantık, Dil, Düşünce, İletişim, Dil-Mantık İlişkisi

\section{Giriş}

İnsan, konuşan, $\operatorname{logosa}^{1}$ sahip hayvan/canlıdır. Bundan dolayı insan, düşünen bir canlıdır. İnsan, konuşan ve düşünen bir canlı olma özelliğiyle kendisini diğer canlılardan

1 Logos: akla, sebebe ve özellikle de mantığa başvurmak şeklinde isimlendirilir. Logos terimine kavramsal açıdan bakılacak olursa; bu konuda bk. Güler Çelgin, “Logos”, Eski Yunanca-Türkçe Sözlük (İstanbul: Kabalcı 
farklı kılmaktadır. İnsan, fiziksel olarak var olmanın yanı sıra duygusunu, düşüncesini, tecrübesini, becerisini ve bilgisini paylaşmak ya da aktarmak ister. Bunu da insan, dil ile gerçekleștirebilir. Dil, iletişim araçlarından birisi olması hasebiyle insanlar var olduğu süre içerisinde kendi aralarında iletişim kurmak için dili kullanabilir. İletişim gerçekleşirken dil kadar dilin doğru, düzgün ve tutarlı bir şekilde kullanılması da önemlidir. Bundan dolayı insanlar kendi aralarında düşüncelerini paylaşırken dili doğru ve tutarlı kullanmalıdırlar. Bunun yanında paylaşılan ya da aktarılan düşüncenin tutarlı olabilmesi için mantığa ihtiyaç vardır. "Sağlam bir mantık bilgisinin günlük pratik sorunların çözümünde; davranışlarımızı motive eden bir takım kabullerin doğruluğunun araştırılmasında; grup ve cemaatlerin temel kabullerinin anlaşılması, tartılması ve değerlendirilmesinde; farklı inanç ve düşüncedeki kişilerin delillerinin tartılması, onların ikna edilmesi yahut çürütülmesinde (cedel); neden neyin çıkacağını ne neyin neye delalet edeceğini düşünerek, seri ve isabetli kararların verilmesinde etkin bir araç olduğu inkâr edilemez." Kısaca mantık, her alanda kendini ciddi oranda hissettirmektedir. Dolayısıyla insanlar, kendi aralarında iletişim kurarken dile ve mantığa ihtiyaç duymaktadırlar. Bu bağlamda ele alınacak olan dil ve mantık ilişkisi, çalışmamızın konusunu oluşturmuş olacaktır.

Sağlam düşünme, doğru ve kesin yargilarda bulunma ile geçerli ve tutarlı argümanlar kullanma amacında olan insanın düzgün iletişim kurmasının yanında sağlam düşüncelerini aktarması için dile ve mantığa ihtiyacı olduğu aşikârdır. Bundan dolayı çalışmamızda öncelikle dil ve mantığın ne olduğu ile ilgili malumatı verdikten sonra aralarındaki ilişki üzerinde durmaya çalışacağız.

\section{Dil Nedir?}

Dil hakkında tarih içerisinde birçok tanımın yapıldığı görülmektedir. Yapılan bu tanımlarda ön plana çıkan durum; dilin iletişim vasıtası olduğudur. Bu da dilin işlevsellik açısından en önemli yönüdür. İnsan, iletişimi her ne kadar sembollerle, işaretle ya da jest ve mimiklerle yapabiliyor olsa da esas olarak sözlü bir şekilde gerçekleştirmektedir. Bundan dolayı dilin sözlü olması onun önemli özelliklerindendir.

Dilin tanımlarından bazılarına burada yer vermek gerekirse şu tanımları sıralayabiliriz:

İnsanların düşündüklerini ve duyduklarını bildirmek için kelimelerle veya işaretlerle yaptıkları anlaşma, lisan, zeban; Bir çağa, bir gruba, bir yazara özgü söz dağarcığı ve söz dizimi; Düşünce ve duyguları bildirmeye yarayan herhangi bir anlatım aracı; ${ }^{3}$

Bir iletişim yöntemi olarak kullanılan konuşma formlarından meydana gelen yapı ya da bütün. Bireylerde karşıllklı olarak, sistematik bir ilişki içinde bulunan ve sözcük düzeyinde uzlaşım yoluyla oluşan bir anlama sahip olan birimlerden meydana gelen sistem. Duyuları, düşünceleri, seçimleri açıkça göstermeyi mümkün kılan her türlü işaret sistemi olarak dil, bilinç içeriklerini duyguları, arzuları, düşünceleri tutarlı bir anlam çerçevesi ya da modeli içinde ifade etme yolu ya da yöntemini tanımlar. ${ }^{4}$

\footnotetext{
Yayınevi, 2010), 402; Ahmet Cevizci, “Logos”, Felsefe Sözlüğü (İstanbul: Paradigma Yayıncilık, 2005), 1087; Coşkun Baba, Retoriğin İkna Gücü (Konya: Çizgi Kitabevi, 2018), 130-172.

2 İbrahim Emiroğlu, Klasik Mantığa Giriş (Ankara: Elis Yayınları, 2009), 35.

3 Türkçe Sözlük, "Dil” (Erişim 13 Haziran 2019).

4 Cevizci, Felsefe Sözlüğü, 486.
} 
İnsanlarin tekellüm ettikleri lehçelerin beheri, lügat, lisan, zeban. ${ }^{5}$

Yukarıdaki tanımlardan yola çıkarak diyebiliriz ki; dil, insanın duygularını, düşüncelerini, arzularını dışa vurmasına imkân sağladığı gibi hayatını sürdürmesine de olanak sağlar. Dil olmadan insan bunları açığa vuramayacağı gibi hayatını da sürdürmekte zorlanacaktır. Değişken olan dil, bildirişme dizgelerinin en gelişmişi, en ergini olarak karşımıza insan dili şeklinde çıkmaktadır. İnsanın ve uygarlığın en önemli belirtisi ve vasıtası olan dil, her açıdan önem taşımasına rağmen çok farklı sorunlarla da karşımıza çıtı̆̆ı olmaktadır. Bundan dolayı dillerin kendilerine has kanunları, problemleri ve eğilimleri vardır.

Düşüncenin veya anlamın taşıyıcısı ${ }^{7}$ dilin anlam taşıyan en küçük birimi kelime yani sözcüktür. Kelimeler, dilin kendi kuralları çerçevesinde bir araya gelerek anlamlı cümleleri, cümleler de yazılı ya da sözlü metinleri oluştururlar. Bu metinler bir takım zihin etkinliğinin dilde varlığa gelen biçimleridir. Bu açıdan bakıldığında anlam, ya bir kavram ya bir cümle ya da bir akıl yürütmedir. Kavram ve cümle, dilbilime ait terimler iken akıl yürütme, mantığa aittir. Burada şunu da belirtmek gerekir ki; kavrama mantıkta terim denirken terimlerin oluşturduğu cümleye de önerme denir. Terimler önermeleri, önermeler ise akıl yürütmeleri ve özellikle de akıl yürütme yollarından dedüksiyonun en iyi yolu olan kıyası oluşturmaktadır. ${ }^{8}$ Bundan dolayı mantık ve dil iç içe geçmiş olup bir bütün halinde oldukları açıktır.

\section{Mantik Nedir?}

Düşüncenin aktarılması bağlamında düşüncenin veya anlamın taşıyıcısı olan dil, düşüncenin aktarımı için olmazsa olmazıdır. Düşüncenin doğru ve tutarlı olması hususunda önemli rol oynayan mantık ile dil arasındaki ilişkiyi ortaya koyabilmek için mantığın da ne olduğunu belirtmemiz gerekmektedir.

İlk olarak mantığın kelime anlamı üzerinde durmak gerekirse, Yunanca "Logike" sözcüğünün Arapça karşıllğı olan "Mantık” sözcüğü “konuşmak (söz)/düşünmek” manasına gelen 'nutk' (nutuk) kelimesinden türetilmiştir. 'Nutk' kelimesi Grekçede akıl, akıl yürütme, düşünme ve konuşma anlamlarına gelen "logos” kelimesinin karşılığıdır şeklinde söyleyebiliriz. İkinci olarak dil mantık ilişkisi bağlamında mantığın bazı tanımlarını burada belirtmek gerekirse şu tanımları sıralamak mümkündür:

Mantık, doğru ve düzgün düşünme ya da tutarlı düşünme yani mantıklı düşünme kurallarının ve biçimlerinin bilgisidir.

Mantık, düşünme yasalarının bir bilimidir.

Mantık, dil ile ifade edilen düşüncelerin formal yasa ve şartlarının bilgisidir.

\footnotetext{
Şemseddin Sami, Kamus-ı Türki (Anakara: Türk Dil Kurumu Yayınları, 2015), 257.

Doğan Aksan, Bütün Yönleriyle Dil (Ankara: Türk Dil Kurumu Yayınları, 2015), 11-13.

Abdulkuddüs Bingöl, “İletişim Bağlamında Mantık ve Dil”, İstanbul Üniversitesi İletişim Fakültesi Hakemli Dergisi, 9 (1999), 107.

8 Bingöl, “İletişim Bağlamında Mantık ve Dil”, 107.

9 Bu konuda bk. Necati Öner, Klasik Mantık (Ankara: Ayyıldız Matbaası, 1986), 1; Necip Taylan, Mantık Tarihçesi Problemleri (İstanbul: MÜ İFAV Yayınları, 1996), 9; Abdülkadir Çüçen, Klasik Mantık (Bursa: Asa Kitabevi, 2004), 15; Emiroğlu, Klasik Mantığa Giriş, 11; İbrahim Çapak, Gazali’nin Mantık Anlayışı (Ankara: Elis Yayınları, 2011), 11; İbrahim Çapak, Ana Hatlarıyla Mantık (İstanbul: Ensar Neşriyat, 2015), 13; Coşkun Baba, "Bilgi Bağlamında Doğruluk ve Mantık İlişkisi Üzerine”, Doğru Üzerine, ed. Murat Kelikli (Ankara: Elis Yayınları, 2018), 35.
} 
Mantık, bilinenden bilinmeyene ulaştıran bir bilimdir.

Mantık, kurallarına uyulduğu takdirde zihni hatadan koruyan bir fen, bir bilim ya da düşüncenin/fikrin doğru ve geçerli olanını bozuk ve geçersiz olanından ayırma konusunda insana kurallar sunan bir alet ilmidir. ${ }^{10}$

Yukarıda verdiğimiz tanımlardan yola çıkarak; mantık bilindiğinde, sözün doğrusunu yanlış ve geçersizinden ayırt edilebildiği gibi manayı doğru kavramayı da yanlış olanından ayırt edilebilir diyebiliriz. Mantığın konusu mantıksal düşünmedir. Bundan dolayı mantık, "doğru düşünme kurallarının/yasalarının bilgisi” diye tanımlanmaktadır. ${ }^{11}$ Mantık ve dilin ortak paydası 'düşünce' ve 'düşünme'dir. Çünkü hem mantık hem de dil, 'düşünme’ ile sıkı ilişki içerisindedir. Dilin düşünce ile olan ilişkisi ve düşüncenin de mantıkla olan ilişkisi dikkate alındığında mantık dil ile de sıkı ilişki içerisindedir sonucuna ulaşılabilir. Zaten "tüm sofistler "doğru düşünmek için doğru konuşmak gerekir" diyerek ve bunu bir özdeyiş haline getirerek, dil-mantık ilişkisinin farkında olduklarını göstermişlerdir." ${ }^{12}$ Logos yani mantık temelinde söz söylemek ya da konuşmak, varlıkla düşüncenin kaideleri arasındaki uygunluğu/tutarlılı̆̆ı dile yansıtmaktır. ${ }^{13}$

\section{Mantık - Dil Münasebeti}

Mantığın dil ile olan münasebetini açıklamaya çalışırken öncelikle şu bilgilere yer vermek yerinde olacaktır. "Dil düşüncenin elbisesidir" . ${ }^{4}$ "Yine Heidegger'e göre, 'dil, insanın evidir' 'dil varlığın evidir' 'dil düşüncenin evidir”. 15 "Dil, hakikaten aynen bir evin özelliklerini barındırmaktadır. Evin özelliklerine benzer şekilde bir toplumun düşünce, duygu ve yaşamının sığınağı, korunağıdır. İnsanın dil sistemi içerisinde var olduğu söylenebilir. İnsan, dil içinde yaşadığı için onun bütün hayat tecrübesinin, diline yansıdığı görülebilir. (...) Düşünceler, dünyayı nasıl tam olarak yansıtıyorsa, dil de düşünceleri tam ve dosdoğru olarak yansıtmalıdır. Bu yüzden dildeki özne-yüklem ilişkisi önemlidir. Bir cümledeki özne-yüklem arasındaki gramer ilişkisi, nesne ile nitelikleri arasındaki ontik ilişki gibidir. Nasıl ki nitelikler nesnesinden soyutlandığında bir nesne tanımı yapılamıyorsa, özne ile yüklem arasındaki gramer ilişkisi de olmadan dilin düşünceyi doğru olarak yansitmasından söz edilemez."

Mantık, doğru düşünmenin vasıtasıdır. Yukarıda da belirtildiği üzere dil de düşüncenin elbisesidir. Dili şekillendiren ya da dile şekil veren esasında düşüncedir. Düşünceler,

10 Öner, Klasik Mantık, 4; Taylan, Mantık Tarihçesi Problemleri, 10; Çüçen, Klasik Mantık, 16-17; Emiroğlu, Klasik Mantığa Giriş, 12-13; Çapak, Ana Hatlarıyla Mantık, 14-15.

11 Cemal Yıldırım, Mantık ‘Doğru Düşünme Yöntemi’ (Ankara: Bilgi Yayınevi, 1999), 15.

12 Doğan Özlem, Mantık (İstanbul: Anahtar Kitaplar Yayınevi, 1996), 307.

13 Hasan Ayık, “Düşünceden Dile Felsefe ve Metafor”, Milel ve Nihal İnanç, Kültür ve Mitoloji Araştırmaları Dergisi, 6/1 (Ocak - Nisan 2009): 56.

14 David Sebberson, "The Rhetoric of Inquiry or the Sophistry of the Status QUO? Exploring the Common Ground between Critical Rhetoric and Institutional Economics?", Journal of Economic Issues, 24/4 (1990): 1019; Ernst Von Aster, İlkçağ ve Ortaçağ Felsefe Tarihi, çev. Vural Okur (İstanbul: İm Yayınları, 2005), 254; Ali Osman Gündoğan, “Dil, Düşünce ve Varlık İlişkisi”, Türk Yurdu, 178 (2002): 20.

15 Martin Heidegger, Hümanizmin Özü, çev. Ahmet Aydoğan (İstanbul: İz Yayınc1lık, 2002), 37; Mehmet Kaplan, Kültür ve Dil (İstanbul: Dergâh Yayınları, 2000), 163; Nadir İlhan, “Toplumsal ve Ferdi Düşüncenin Dile Yansımaları (Dil-Düşünce İlişkisi)”, Turkish Studies, 7/3 (Summer 2012): 1522.

16 Baba, Retoriğin İkna Gücü, 132. 
dil ile ifade edilmesi gerekir, zira düşüncelerimizi dil ifade etmezsek mantıksal açıdan inceleyebilmemiz söz konusu olmayacaktır.

Akıl yürütmeler bir düşünme türü olarak zihinsel bir olgu ${ }^{17}$ olduğu dikkate alınd1ğında düşüncelerin mantıksal geçerliliğini, tutarlılığını belirleyebilmek için öncelikle akıl yürütmelerin (çıkarımların) dil aracılığıyla ifade edilmesi yani dışa vurulması ve bir argüman/iddia/tez/kanıt şeklini alması gerekmektedir. Böylece mantığın inceleme alanına giren nesnel nitelikli argümanlar mantığın konusunu oluşturur. ${ }^{18}$

Mantık, aslında düşünceyle beraber varlığını sürdüren ve dil sayesinde kendini ifade etme imkânı bulan, dışa vuran bir süreç olduğu söylenebilir. Mantık denildiğinde düşünceyle birlikte hangi şekilde ya da koşulda olursa olsun dilin, diğer bir ifade ile düşünülenin ifade edilme hali akla gelmektedir. ${ }^{19}$ Bundan ötürü dil, düşünce ve mantık aralarında kesin ve sıkı ilişkisi içerisindedir.

Tekrar vurgulamak gerekirse hem "nesnel düşüncenin kurallarını koyan mantık ilmi”"20 hem de dil, 'düşünme' ile sıkı ilişki içerisindedir. Bundan dolayı mantık da dil ile doğrudan alakalıdır. Mantık sayesinde düşünme eylemi sağlıklı, sağlam (bilgi açısından), tutarlı ve doğru olmaktadır. Buradan hareketle; mantık sayesinde sağlam düşünce oluşmuş ise sağlam düşünceden sağlam bir dilin ortaya çıkma ihtimalide artmıştır denebilir.

Mantık, doğru düşünmenin vasıtası olmasıyla aynı zamanda retoriğin de epistemik açıdan sağlam olmasına vesile olmaktadır. Düşünmenin temel yasalarını ortaya çıkaran, düzene koyan, bu yasalar arasında olması gereken ilişkiyi ve birlikteliği sağlayan mantık ilmidir. Bundan dolayı bilginin kesinliğini sağlayan da bu kurallara dayalı çıkarımlardır. Mantık doğru ve tutarlı düşünmenin nasıl olması gerektiği ile ilgilenirken düşünceyi ifade eden dil ile de ilgilenmektedir. Çünkü yukarıda da belirttiğimiz gibi dil, düşüncenin taşıycısıdır. Düşüncelerimizi açıklamada kullandığımız dilin anlam taşıyan en küçük birimi kelimeler yani sözcükler hem düşüncelerimizi hem de duygularımızı ifade etmektedirler.

Dil ile mantık arasında sıkı bir ilişkinin varlı̆̆ından rahatlıkla söz ediyor olabilmemize etken sebeplerden bir başkası da şudur: "Dilbilgisi hatasız konuşmanın, mantık da doğru düşünmenin kurallarını vermektedir. Dilin lafızlarla olan ilişkisi ne ise mantığın kavramlarla ilişkisi de öyledir. Şu var ki gramer bir milletin diliyle ilgili kuralları içerirken mantık bütün insanlığın düşüncesine ait kanunları ifade etmektedir. Mantık, kullanılan dilin, terimlerin sınırlarının iyi çizilmesini, anlam belirsizliğine veya çok anlamlılığa kayılmamasını, sınırlarının belli, kullanış şekillerinin belirgin kısacası, kullanılan dilin açık, seçik ve kesin olmasını talep eder." ${ }^{21}$

Dil mantık ilişkisi bağlamında mantık, akla gelebilecek her türlü zihinsel aktivitenin vazgeçilmez bir unsurudur. Mantık, düşünmenin kurallarını belirler, doğru ve yanlışın

17 Cemal Yıldırım, 100 Soruda MantıkEl Kitabı (Isstanbul: Gerçek Yayınevi, 1976), 10.

18 Öner, Klasik Mantık, 14; Emiroğlu, Klasik Mantığa Giriş, 26; Yıldırım, Mantık ‘Doğru Düşünme Yöntemi', 17; Yıldırım, 100 Soruda Mantık El Kitabı, 10; Gültekin Eroğlu, “Akıl Yürütme Formlarının Mantık ve Bilimlerde Yeri ve Değeri”, Hikmet Yurdu, 5/10 (Aralık 2012), 184.

19 Necip Taylan, Ana Hatlarıyla Mantık(İstanbul: Ensar Neşriyat, 2008), 14; İbrahim Karataş, "Bulanık Mantık ile Klasik ve Sembolik Mantık İlişkisi (Karşılaştırılması)”, European Journal of Educational \& Social Sciences, 3/2 (October 2018): 148.

20 Aylk, "Düşünceden Dile Felsefe ve Metafor", 71.

21 Emiroğlu, Klasik Mantığa Giriş, 26; İbrahim Emiroğlu, Mantık Yazıları (Ankara: Elis Yayınları, 2016), 35. 
kıstaslarını bildirir. Bir bilginin tutarlı, doğru ve kesin olabilmesi, mantık kurallarına riayet etmekle mümkündür. Bu durumu bir başka ifade ile şöyle açılayabiliriz: "Müzik için nota, şiir için aruz ne ise, teorik bilgi için mantık da odur". ${ }^{22}$ Burada Abdulkuddüs Bingöl'ün dil ile mantık arasındaki ilişkiyi anlatmak için yaptı̆̆g benzetme ve değerlendirmesine de yer vermek yerinde olacaktır. "Sanki mantık, betonarme bir binanın kargası gibi bir iskelet verir, geriye kalan dolgu malzemesidir. İnsan o kargasa dilediği dolgu malzemesini koyar. Ama malzemeyi nereye ve nasıl koyacağını kargas dikte eder. Denilebilir ki, her dilsel iletişimin gerisinde bir mantık akışı görmemek mümkün değildir. Hatta mantıksızlıkla suçladığımız durumlarda bile."³

Zihnimizi hataya düşmekten koruyan mantık, dil sayesinde kendisine ifade alanı bulur. Doğru ya da yanlış şeklinde nitelendirilen düşünceler ve kavramlar her zaman dil vasıtasıyla meydana çıkar. Dolayısıyla herhangi bir akıl yürütmenin mantıksal açıdan geçerliliğini belirleyebilmek için her şeyden önce o akıl yürütmesinin dil vasıtasıyla dışa vurulup bir argüman biçimi kazanması gerekmektedir. Bundan dolayı mantık, akıl yürütmelerin dilsel ifadesi olan argümanlarla ilgilenir. ${ }^{24} \mathrm{Bu}$ nedenle de akıl yürütmelerin dilsel ifadesi olan argümanlarla ilgilenen mantığın dil ile kopmayan bir bağı ve ilişkisi vardır.

İster yazılı metinler olsun isterse sözlü metinler olsun bunlar kendilerini dil ile dışa vururlar. Dil vasıtasıyla dışa vurulmuş yazlı/sözlü metinlerin doğru ve tutarlı olması ise mantık sayesinde olacaktır. İnsan düşüncesini dışa vururken genellikle yazılı ya da sözlü dili kullanır. Yazılı veya sözlü dilin kullanıldığı yerlerde aktarılan düşünce, mantık kuralları kullanıldığı takdirde doğru ve tutarlı olacaktır ya da diğer bir ifade ile mantıklı düşünce gerçekleşmiş olacaktır.

Dil, karşımıza "anlam taşıyıcısı ve insan düşüncesini kuşatan ve kapsayan” ${ }^{25}$ bir unsur olarak çıkmaktadır. Bu anlam taşıyıcılığında sözler, kavramlar, önermeler etkindir. "Sözün açıcça-dile getirilmişliğine dil"² dendiğine göre bu dil, "anlama ve yorumlamada belirleyici bir rol”27 oynamaktadır. Anlama, herhangi bir şeyin anlaşılmasından sonra dile dökülmesi değil, anlaşılmış olan şeyin dile gelişi olmasından ötürü tüm anlama dilde gerçekleşir ki bu da sadece dil ile mümkün olmaktadır. ${ }^{28}$ Esasında dil, bunları yaparken dilde iletişimi sağlayan ası ögeler olan önermelerden faydalanmaktadır. Hüküm bildiren önermeler de mantığın konuları içerisinde yer almaktadır. Bundan dolayı önermeleri konu edinen mantık, önermeler vasıtasıyla iletişimini sağlayan dil ile sıkı bir ilişki içerisindedir.

Ayrıca bilgi, belirli bir yargı şeklinde dile getirilmiş olan önermesel bilgiyi kapsar. ${ }^{29}$ Önermesel bilgiler mantık kurallarına uyulduğu takdirde elde edilebilecek bilgilerdir. Bilgi, dilde -sözlü ya da yazılı olarak- ifade edilir. "Bilgi dilde ifade edildiğine göre, doğru

22 Bingöl, “İletişim Bağlamında Mantık ve Dil”, 108.

23 Bingöl, “İletişim Bağlamında Mantık ve Dil”, 108.

24 Öner, Klasik Mantık, 14; Emiroğlu, Klasik Mantığa Giriş, 26.

25 Mehmet Ulukütük, “Geleneğin Dili mi Varlığın Evi mi? Heidegger ve Gadamer'de Dil, Gelenek ve Varlı̆̆ın İnsanlık Halleri Üzerine”, Özne Felsefe Bilim ve Sanat Yazıları Dergisi 17 (Bahar 2012): 5.

26 Martin Heidegger, Varlıkve Zaman, çev. Kaan H. Ökten (İstanbul: Agora Kitaplı̆̆ı, 2008), 170.

27 Ulukütük, “Geleneğin Dili mi Varlığın Evi mi?”, 5.

28 Hans-Georg Gadamer, Hakikat ve Yöntem II, çev. H. Arslan - İ. Yavuzcan (İstanbul: Paradigma Yayınları, 2009), 163-164.

29 Nebi Mehdiyev, Çağdaş Epistemolojiye Giriş (İstanbul: İnsan Yayınları, 2011), 11. 
bilgi, düşünceden başlayarak önermelerin, yargıların ve çıkarımların doğruluğudur. Bu durumda önermelerin doğruluğunun ve yanlışlığının bilinmesine ihtiyaç duyulur. Önermeler ve yargı meselesi ise epistemolojinin mantıkla yollarının kesiştiği noktadır... Mantık, bilginin biçimi ile yani bilginin ifade edildiği önermelerin ve akıl yürütmelerin doğruluk değeriyle ilgilidir... klasik mantık, bilginin elde ediliş sürecinde doğru düşünmek ve doğru çıkarımlarda bulunmak için gerekli teknik yöntemleri sunar." 30

Mantığın kurucusu olan Aristoteles (MÖ 384-322) ìlkçağ’da dili incelerken mantıksal bir yaklaşım sergilemiştir. Dildeki kelimelerin düşünmenin birer ögesi olduğunu vurgulayan Aristoteles'e göre "konuşma düşünceye uygun olduğuna göre dil eşyayı yansıtmak için düşüncenin buyruğunda olan bir araçtır." ${ }^{31}$ Bu yüzden dil, düşünceyi tam ve dosdoğru yansitmalıdır. Düşüncenin tam ve doğru bir şekilde yansıtılabilmesi için dil ile birlikte mantığa da ihtiyaç vardır. Çünkü ifadeler, mantık kurallarıyla, delillerle ve bilgi ile doğrulanmaktadir. ${ }^{32}$

Tarihe bakıldığında görülecektir ki; dil ve mantık alanlarındaki dersler her zaman önemsenmiştir. Bu minvalde şu alıntı da dil mantık ilişkisi ile ilgili durumu ortaya koyacaktır. Şöyle ki: "İslâm toplumu ve kültürünün dil esaslı olması, bu toplum ve kültürün kendi varlığını, kendi esasları ile olan irtibatını muhafaza ederek, sürdürebileceğini de göstermektedir. Bundan dolayı, dil bilimleri, İslâm kültürü içinde gelişen ilk ilimlerden olmuş; İslâm medeniyetinin ortaya çıkardığı en güçlü devlet ve İslâm medeniyetinin en olgun meyvesi olan Osmanlı döneminde, medresede temel eğitimin üzerinde yükseldiği iki temelden birisi (diğeri mantık) olarak, asırlarca, Osmanlı toplumunda benzerini başka bir yerde göremediğimiz oldukça özgün bir ilim ve eğitim anlayışının temel direklerinden (sacayağının üç ayağından birisini, diğer ikisi mantık ve tasavvuf teşkil etmektedir) birisini teşkil etmiştir." 33

Son olarak, dil ile mantık arasındaki sıkı ilişkiden söz etmemize destek olacak bir görüşe daha yer vermek konumuzun anlaşılmasına yardımcı olacaktır. Şöyle ki, nutuk (konuşma, söz) kelimesinden türeyen mantık Ali Sedat'a göre, iç konuşma ve dış konuşma manalarına gelmektedir. İç konuşma, akledilmiş olan manaların anlaşılması ya da idraki, bir başka ifade ile akledilmiş anlamların zihni düzenlemesidir. ${ }^{34}$ Iç konuşma aşamasını sağlam bir hale getiren mantık daha sonra dış konuşmayı yine kendi kurallarıyla hatasız, sağlam ve mükemmel hale getirmektedir. Dış konuşmanın gerçekleşmesi dil ile olmaktadır. Dilin çok anlamlılıktan kurtulup tek anlamlı hale gelmesi mantı̆̆ın kuralları ile mümkündür ki, bu da dilin olgunlaşmasını sağlar. Dolayısıyla dilin olgunlaşabilmesi için mantığa ihtiyaç vardır. ${ }^{35}$ Bu bilgilerden hareketle kısaca iç konuşmanın mantık, dış konuşmanın ise

30 Hülya Altunya, Klasik Mantık Açısından Hakikat ve Şiir (İstanbul: Büyüyen Ay Yayınları, 2014), 125126.

31 Von Aster, İlkçă̆ ve Ortaçă̆ Felsefe Tarihi, 254.

32 John Wilson, Dil, Anlam ve Doğruluk, çev. İbrahim Emiroğlu - Abdullatif Tüzer (Ankara: Ankara Okulu Yayınlar1, 2002), 13.

33 Tahsin Görgün, İlahi sözün Gücü (İstanbul: Külliyat Yayınları, 2013), 58.

34 Ali Sedat, Lisanu'l Mizan (İstanbul: Karabet ve Kasbar Matbaası, 1306/1890), 120; Hasan Ayık, "Ali Sedat Mantığında Dil-Düşünce İlişkisi” Sosyal Bilimler Dergisi, 2/28-29 (2002), 270.

35 Hasan Ayık, “Ali Sedat Mantığında Dil-Düşünce İlişkisi”, 270. 
mantık kuralları ile dizayn edilmiş dil olduğunu söyleyebiliriz. Bu sebepledir ki “dil ve mantık bir bütüne aittir". ${ }^{36}$

Mantık kuralları ile düzenlenen sağlıklı, sağlam, tutarlı ve doğru düşünce, mantık kuralları olmadığında yanlışa düşmektedir. Bu yanlışlık da devamında dile yansımaktadır. Çünkü zihindeki iç konuşmanın (düşünce), dış konuşmada olduğu gibi, kendisini düzenleyecek kurallara ihtiyacı vardır. Nasıl ki dış konuşmayı gerçekleştiren dil, dilbilgisi kurallarına riayet etmeksizin düzenlendiğinde gramatik bakımdan doğru olmuyorsa, aynı şekilde iç konuşma da mantık kurallarına uygun olarak düzenlenmediği zaman düşünce yanlışa düşmüş olacaktır. Dolayısıyla mantık kurallarına uygun düzenlenmiş düşünce ile dil arasında sıkı bir bă̆, ilişki vardır. ${ }^{37}$

\section{Sonuç}

Düşünen ve mantığını kullanan ya da akleden bir canlı olan insan, düşünce ve duygularını dil sayesinde dışa aktarmaktadır. Düşüncelerin dışa aktarılması sırasında ifadelerin doğru olmasında dile ait kurallar kadar doğru ve tutarlı düşünmenin yasa ve kaideleri de önem arzetmektedir. Doğru ve tutarlı düşünmenin yani mantıklı düşünmenin kuralları da mantık ilminin belirlediğini unutmamak gerekir. Bundan dolayı mantık ve dil arasında sağlam bir bağ olduğu ve sıkı bir ilişkinin bulunduğu rahatlıkla söylenebilir.

Mantık bilindiğinde, doğru söz yanlış olanından ayırt edildiği gibi doğru mana da yanlış olanından ayırt edilmektedir. Mantığın konusu mantıksal düşünmedir. Dili şekillendiren ya da dile şekil veren esasında düşüncedir. Düşünceler, dil ile ifade edilmesi gerekir ki dışa aktarımı gerçekleşebilsin. Düşünceler, dil aracılığıyla ifade edildiğinde argüman şeklini kazanmaktadır. Mantık ilminin inceleme alanına giren argümanlar mantığın konusunu oluşturur. Dolayısıyla hem mantık hem de dil, 'düşünme' ile sıkı ilişki içerisindedir. Mantık ve dilin ortak paydası 'düşünce' diğer bir ifade ile 'düşünme'dir. Çünkü hem mantık hem de dil, 'düşünme' ile sıkı ilişki içerisindedir. Mantık, aslında düşünceyle beraber varlığını sürdüren ve dil sayesinde kendini ifade etme imkânı bulan, dışa vuran bir süreç olduğu söylenebilir. Mantık denildiğinde düşünceyle birlikte hangi şekilde ya da koşulda olursa olsun dilin, diğer bir ifade ile düşünülenin ifade edilme hali akla gelmektedir. Dolayısıyla mantık ve dil birleriyle sıkı ilişki içerisinde olup birbirleriyle doğrudan alakalidir.

Mantıklı düşünme, doğru yargılarda bulunma ve geçerli argümanlar kullanma amacında olan insanın bu amacını yerine getirebilmek için öncelikle akıl, mantık ve dile ihtiyacı vardır. Dolayısıyla burada olduğu gibi iletişim sırasında da iletişimin sağlıklı yürütülebilmesi için mantık ile dil önemli rol üstlenmektedirler. Bu sebeple iletişim için mantık ve dile ihtiyaç vardır. Netice itibariyle dil ile mantık birlikte olmak durumundadırlar. $\mathrm{Bu}$ durum da bize göstermektedir ki, dil ile mantık arasındaki ilişki her zaman güçlü bir şekilde devam etmek zorundadır.

Kısaca hayatın her alanında dili kullan bir varlık olarak insan mantı̆̆ı da kullanmak durumundadır. Zira insan, mantı̆̆ın kurallarına uygun hareket etmezse insan zihninin

36 Felsefeciler Derneği, "Mantık nedir, herkes mantıklı mıdır? / Gülgün Türkoğlu”, erişim: 27 Ekim 2019, http://www.felsefecilerdernegi.org.tr/mantik-nedir-herkes-mantikli-midir-gulgun-turkoglu.

37 Hasan Ayık, Farabî̀de Dil-Mantık İlişkisi (İstanbul: Köprü Kitap, 2019), 176. 
hataya düşmesi kaçınılmazdır. Bu sebeple mantık, çoğu zaman iletişim halinde olan insanların hayatında dil ile birlikte önem arz etmektedir. Çünkü dil olmadan mantık, mantık olmadan da dil önemsizdir. Bundan dolayı da 'mantık'sız 'dil', 'dil'siz 'mantık' düşünme tasavvur edilemez.

\section{Kaynakça}

Aksan, Doğan. Bütün Yönleriyle Dil. Ankara: Türk Dil Kurumu Yayınları, 2015.

Ali Sedat. Lisanu’l Mizan. İstanbul: Karabet ve Kasbar Matbaas1, 1306/1890.

Altunya, Hülya. Klasik Mantık Açısından Hakikat ve Şiir. İstanbul: Büyüyen Ay Yayınları, 2014.

Ayık, Hasan. “Ali Sedat Mantığında Dil-Düşünce İlişkisi”. Sosyal Bilimler Dergisi 2/28-29 (2002), 267-276.

Ayık, Hasan. Farabî'de Dil-Mantık ilişskisi. İstanbul: Köprü Kitap, 2019.

Ayık, Hasan. "Düşünceden Dile Felsefe ve Metafor". Milel ve Nihal İnanç, Kültür ve Mitoloji Araştırmaları

Dergisi 6/1 (Ocak - Nisan 2009), 55-73.

Baba, Coşkun. “Bilgi Bağlamında Doğruluk ve Mantık İlişkisi Üzerine”. DoğruÜzerine. Ed. Murat Kelikli.

35-76. Ankara: Elis Yayınları, 2018.

Baba, Coşkun. Retoriğin İkna Gücü. Konya: Çizgi Kitabevi, 2018.

Bingöl, Abdulkuddüs. “ïletişim Bağlamında Mantık ve Dil”. İstanbul Üniversitesi İletişim Fakültesi Hakemli Dergisi 9 (1999), 105-115.

Cevizci, Ahmet. “Logos”. Felsefe Sözlüğü. İstanbul: Paradigma Yayınc1lı, 2005.

Çapak, İbrahim. Ana Hatlarıla Mantık. İstanbul: Ensar Neşriyat, 2015.

Çapak, İbrahim. Gazali'nin Mantık Anlayışı. Ankara: Elis Yayınları, 2011.

Çelgin, Güler. “Logos”. Eski Yunanca-Türkçe Sözlük. İstanbul: Kabalcı Yayınevi, 2010.

Çüçen, Abdülkadir. Klasik Mantık. Bursa: Asa Kitabevi, 2004.

Emiroğlu, İbrahim. Klasik Mantığa Giriş. Ankara: Elis Yayınları, 2009.

Emiroğlu, İbrahim. Mantık Yazıları. Ankara: Elis Yayınları, 2016.

Ernst von Aster. İlkçağ ve Ortaçağ Felsefe Tarihi. çev. Vural Okur. İstanbul: İm Yayınları, 2005.

Eroğlu, Gültekin. “Akıl Yürütme Formlarının Mantık ve Bilimlerde Yeri ve Değeri”. Hikmet Yurdu 5/10 (Aralık 2012), 183-196.

Gadamer, Hans-Georg, Hakikat ve Yöntem II. çev. H. Arslan - İ. Yavuzcan, İstanbul: Paradigma Yayınları, 2009.

Görgün, Tahsin. İlahi Sözün Gücü. İstanbul: Külliyat Yayınları, 2013.

Gündoğan, Ali Osman. “Dil, Düşünce ve Varlık îlişkisi”. Türk Yurdu 178 (2002), 18-22.

Heidegger, Martin. Hümanizmin Özü. çev. Ahmet Aydoğan. İstanbul: İz Yayınc1lı, 2002.

Türk Dil Kurumu. “Dil”. Erişim: 13 Haziran 2019. https://sozluk.gov.tr/?kelime=dil.

Felsefeciler Derneği. “Mantık nedir, herkes mantıklı mıdır? / Gülgün Türkoğlu”. Erişim: 27 Ekim 2019. http://www.felsefecilerdernegi.org.tr/mantik-nedir-herkes-mantikli-midir-gulgun-turkoglu.

İlhan, Nadir. “Toplumsal ve Ferdi Düşüncenin Dile Yansımaları (Dil-Düşünce İlişkisi)”. Turkish Studies 7/3 (Summer 2012), 1517-1525.

Kaplan, Mehmet. Kültürve Dil. İstanbul: Dergâh Yayınları, 2000.

Karataş, İbrahim. "Bulanık Mantık ile Klasik ve Sembolik Mantık İlişkisi (Karşılaştııılması)”. European Journal of Educational \& Social Sciences 3/2 (October 2018), 144-163.

Martin Heidegger. Varlkve Zaman. çev. Kaan H. Ökten. İstanbul: Agora Kitaplığı, 2008.

Mehdiyev, Nebi. Çağdaş Epistemolojiye Giriş. İstanbul: İnsan Yayınları, 2011.

Öner, Necati. Klasik Mantık. Ankara: Ayyıldız Matbaası, 1986.

Özlem, Doğan. Mantık. İstanbul: Anahtar Kitaplar Yayınevi, 1996.

Sami, Şemseddin. Kamus-ı Türki. Anakara: Türk Dil Kurumu Yayınları, 2015.

Sebberson, David. "The Rhetoric of Inquiry or the Sophistry of the Status QUO? Exploring the Common Ground between Critical Rhetoric and Institutional Economics?". Journal of Economic Issues 24/4 (1990), 1017-1026. 
Taylan, Necip. Mantık Tarihçesi Problemleri. İstanbul: MÜ İFAV Yayınları, 1996.

Taylan, Necip. Ana Hatlariyla Mantık. İstanbul: Ensar Neşriyat, 2008.

Ulukütük, Mehmet. “Geleneğin Dili mi Varlığın Evi mi? Heidegger ve Gadamer'de Dil, Gelenek ve Varlığın İnsanlık Halleri Üzerine”. Özne Felsefe Bilim ve Sanat Yazıları Dergisi 17 (Bahar 2012), 1-26.

Wilson, John. Dil, Anlam ve Doğruluk. çev. İbrahim Emiroğlu - Abdullatif Tüzer. Ankara: Ankara Okulu Yayınları, 2002.

Yıldırım, Cemal. 100 Soruda Mantık El Kitabı. İstanbul: Gerçek Yayınevi, 1976.

Yıldırım, Cemal. Mantık 'Doğru Düşünme Yöntemi'. Ankara: Bilgi Yayınevi, 1999. 